\title{
JPL takes on classified research
}

General to be appointed as new director

\section{Washington}

General Lew Allen Jr, who recently retired as chief of staff of the US Air Force, is reported to be the leading candidate for the directorship of the Jet Propulsion Laboratory (JPL), managed on behalf of the National Aeronautics and Space Administration (NASA) by the California Institute of Technology (Caltech). An announcement of the appointment is expected in the next few weeks.

The selection of General Allen would intensify the concern of some scientists at Caltech and JPL over the growing military role of the laboratory. Last year, the Caltech faculty and NASA agreed that up to 30 per cent of the laboratory's operating funds might come from Department of Defense (DoD) research contracts. Before that, the laboratory had refused to do classified research, under a policy laid down by Dr Bruce Murray (who ceased to be director of JPL on 1 July). The decline in NASA funding prompted Dr Murray to seek a change in that policy.

Dr Marvin Goldberger, president of Caltech, maintains that neither that change nor the appointment of General Allen who he says is a "serious candidate" - will affect JPL's fundamental character. "We have every intention that JPL shall have its primary objectives in the civilian space programme. I can assure you that General Allen's view is coincident with this view."

A JPL scientist involved in the selection process pointed out that Allen has a strong technical and management background. $\mathrm{He}$ holds a $\mathrm{PhD}$ in physics from the University of Illinois, and worked at Los Alamos from 1954 to 1957. Allen directed the Air Force space programme from 1965 to 1972.

Allen declined to comment on the report that he is the principal candidate for the JPL position, and would say only that any announcement would come from JPL. But JPL officials are clearly worried about reaction to the appointment of General Allen, both within the Caltech-JPL community and outside it. Similar worries prompted the laboratory to adopt a tacit policy of not carrying out weapons research and development even with the lifting of the prohibition on classified work. The laboratory also made clear that it would not do "secret work secretly" that is, it would only accept such classified projects as it could at least announce its participation in.

Dr Goldberger stresses, too, that work for DoD is subject to scrutiny by a faculty committee which reviews its "propriety" and its effect on the "overall mission of the laboratory". He also insists "classified work will not jeopardize access to the laboratory by Caltech faculty and students"'.

Dr Arden Albee, JPL's chief scientist, agrees that these precautions are enough to

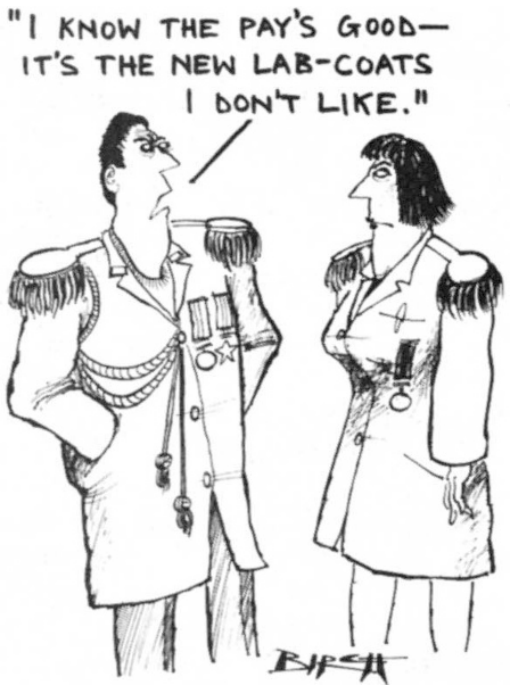

ensure that JPL remains fundamentally a NASA laboratory. "Certainly it's something we have to worry about, but my own feeling is it's not going to cause a significant change in the character of the place", he said.

JPL's principal function within NASA is to provide the engineering and scientific support for unmanned planetary exploration missions. Some of this responsibility is shared with NASA's Ames and Langley laboratories, although JPL is the "lead centre".

At present, "about 8 or 9 per cent" of JPL's support comes from military contracts, according to Dr Albee. These are mostly "small technology projects" involving simulation, sensing and surveillance. The only large project is the autonomous spacecraft project which arose from the Voyager spacecraft work and is of some interest to the Air Force.

Nor does Dr Albee see any new threats to the scientific mission of JPL from its increased involvement in DoD projects: "NASA has always been a development agency; science got done on its periphery. That's as dangerous to science as DoD projects." $\mathrm{He}$ also points out that more research is supported by DoD on the Caltech campus than at JPL.

We have to put it in perspective," he said. "DoD is a major part of the budget. NASA is a small part."

JPL's current budget is $\$ 321$ million; the laboratory employs a full-time staff of 4,620 . The proposed budget for 1983 is $\$ 330$ million, which represents a cut in real terms. According to Dr Arden Albee the most telling indicator of falling NASA support is that the laboratory has not started on a new planetary mission for almost 10 years. Stephen Budiansky

\section{biotechnology}

France has done no microbiology for 20 years, has few people who understand fermentation or fungi and has never developed food processing technology. This wild exaggeration is the opinion of a francophile British biotechnologist sketching the problems facing France in his field. Now, however, a fairy godmother has waved her wand: the ministry of research and industry in Paris has published a vast programme for biotechnology, to stretch over three years and cost the government FF 600 million (about $£ 50$ million). Will she get Cinderella to the ball?

It depends in part on what the report says in a large section marked "Secret and Confidential", which has not been published but which describes the actions to be taken by the ministry in concert with industry. And it depends on whether France can create enough microbiologists, whose star fell faster and further in France than elsewhere when molecular biology turned to the eukaryotic genome. The University of Strasbourg, for example, was granted a new professorship in microbiology last year, with emphasis on biotechnology; it has been unable to fill it, said a spokesman, with anyone with even a smattering of French.

The ministry's three-year programme promises to tackle the problem in partnership with the universities and the grandes écoles. And the Centre National de la Recherche Scientifique (CNRS), which supports much of the most advanced biology in France, plans to help double the number of French microbiologists.

Meanwhile, several important centres of biotechnology will now enjoy increased support. At Toulouse, for example, there are three laboratories grouped to form a kind of "transfer centre" between research Pierre Zaltar (a specialist in gene expression). At Marseilles, there is a laboratory for bacterial microbiology, which will be expanded next year with the help of Orsay biochemist Jean-Claude Patte. At Cadarache, there is a new laboratory for biomass studies run by CNRS in conjuction with the oil company Elf Aquitaine and the Commissariat a l'Energie Atomique. At Compiègne there is the University of Technology with Dr Daniel Thomas specializing in enzyme technology; in Paris, the Institut Pasteur is and industry, directed by Professor Jean- 
working hard to make up for past years; and at the University of Strasbourg, there are well-advanced plans for a laboratory of plant genetics (which is, incidentally, strongly supported by the new report).

This week's report surprisingly emphasises the plant sciences, with no fewer than ten recommendations for INRA, the agricultural research body. Even Professor Roger Monnier, director of life sciences at CNRS, believes plant science must receive the most attention.

Over biotechnology as a whole, the report considers France to be weakest in bioengineering - in the kinetics of growth and production, in techniques of culture of microorganisms and cells, in enzymology, in reactor design, in extraction and purification and in the provision of analytical control equipment. France also suffers because of an "excessive compartmentalization and specialization of disciplines, research organizations and industries" says the report. But it ends on a strong note: now more than ever, France must support fundamental research, which is "the unique source of the unpredictable". $\quad$ Robert Walgate

\section{British Telecom \\ Roll up!}

The British government is embarking on the most significant phase in its plans to liberalize the telecommunications industry. Mr Patrick Jenkin, Secretary of State for Industry, said this week that he will be introducing legislation in November to sell off British Telecom (BT), the stateowned telecommunications monopoly. The subsequent sale of shares will be the "largest single issue on the London market and maybe the world".

The sale of British Telecom has been widely forecast. Earlier in the year it was suggested that the government was considering privatization to avoid acting as guarantor for the company's borrowings. This week, Mr Jenkin confirmed this. But the government clearly hopes that British Telecom will be able to keep down its customer charges, which have recently risen above the cost of services, simply to finance 90 per cent of the annual $£ 2,200$ million investment programme.

The proposal to sell British Telecom goes beyond measures earlier this year to liberalize British telecommunications. Last October, the government passed legislation allowing private companies to supply equipment for attachment to the network in competition with British Telecom. Equipment is still awaiting approval. Earlier this year, the Mercury Consortium, a group of three private companies, was licensed to operate a new telecommunications network in competition with British Telecom. And shortly, $\mathrm{Mr}$ Jenkin promises a general licence permitting the use of BT and Mercury networks by suppliers of value-added or third party services.

The new bill will transform British Telecom into a public limited company and allow the sale of up to 51 per cent of the shares to the public. As soon as half the shares have been sold, the government will relinquish its control, allowing the company to borrow from shareholders and private markets. British Telecom's present status as a licensing authority will be transferred to the industry secretary acting through a newly-created Office of Telecommunications. Regulations balancing the interests of those involved in the supply and use of telecommunication services - will be controlled by the new office. Licences to operate services will be issued, according to $\mathrm{Mr}$ Jenkin, only to those companies willing to fulfil their public duties by, for example, supplying uneconomic services to rural areas.

No doubt still smarting from the embarrassment of under-estimating the share price of Amersham International, sold off earlier this year, Mr Jenkin is as yet unwilling to hazard a guess at the value of British Telecom or the shares that will be on sale. Neither does he seem in any hurry to push the sale through. The legislation can be expected to be enacted by the end of next year, he says. But the sale of shares is not scheduled before the next election, which must occur before May 1984. The present government is clearly confident that it will have another term to run.

Judy Redfearn

\section{Britain's nuclear power}

\section{PWRs hit snag}

Mr Ron Anthony, recently appointed Chief Inspector of Nuclear Installations in Britain, wants to be counted on the side of the angels. Last week his Nuclear Installations Inspectorate (NII) published a report critical of several aspects of the "preconstruction safety report" for a British version of the Westinghouse pressurized water reactor (PWR), thus confounding environmentalists' fears that NII is in the pocket of the nuclear industry.

"As far as we're concerned, no-one could go too far in the matter of safety" said Mr Anthony last week, stressing that assessment of the Central Electricity Generating Board (CEGB)'s design would be continuous right up to the moment of operation. Next January, there will be a planning inquiry on the PWR, but even if the inquiry favoured the reactor, NII would still have the right to refuse a licence.

Is this unexpected opponent causing shudders in the nuclear industry? Not yet. Mr Anthony's inspectoral bark is judged to be worse than his bite. The director of CEGB, Sir Walter Marshall - nuclear physicist and passionate advocate of the PWR - said he was delighted that NII had flexed its muscles, while at the same time giving CEGB a pass mark on all the difficult issues (such as containment vessel design). Moreover, the NII report says frequently that a satisfactory and safe PWR design is "achievable", and that CEGB has only to satisfy NII on certain points.

These are many, and include "human factors" now known to have played a great part in the Three Mile Island accident. "In the preconstruction safety report [for the British PWR] there is only brief mention of the role of the operator in testing and maintenance, operating procedures, operator training, the control room and operator response to faults" says the NII report. "The various sections give little indication of intent to design and operate on good ergonomic principles." NII is not unduly worried, however: CEGB is considering the problem, the inspectorate says, and NII will have evidence of the CEGB conclusion before a licence is granted.

More substantial, in NII eyes, are five concluding points gathered together as "not yet satisfactory". These are:

- Hazards presented by fire, earthquake and aircraft crash.

- "Ballooning" of the fuel cladding.

- Steam generator tube integrity.

- The automatic reactor protection system, which is a completely new design.

- CEGB's software models of fault development.

The report also says that the possible consequences of severe accidents will be the subject of a separate CEGB submission and NII report.

Of all these, Sir Walter Marshall is most worried about ballooning of the fuel cladding, a phenomenon discovered by UK Atomic Energy Authority researchers, Sir Walter's former colleagues. The problem is that uranium fuel rods necessarily contain a small amount of helium and that if the surrounding coolant pressure suddenly drops, this gas can balloon out of the cladding and close off coolant flow completely. For this to happen, the cladding ductility - and hence fuel-rod temperature - has to be just right, and the pressure must not fall too fast (otherwise the cladding simply bursts, allowing coolant past the ragged edges). The combination of conditions is unlikely, but it requires only a small lossof-coolant accident, said Sir Walter. Experiments are under way in Canada to measure precisely the conditions in which ballooning occurs, but Sir Walter "stakes his reputation" in predicting that the phenomenon will prove to be no substantial obstacle to reactor safety.

The automatic reactor protection system is the other, more substantial, doubt. Relying on modern microelectronics and computer control, this system would handle major faults for $\mathbf{3 0}$ minutes before an operator was allowed to touch the controls. NII has no objection to the principle, but remains to be satisfied that it will work. That will require six years of software analysis and testing, said Sir Walter last week. He will set up a team of 10-20 specialists to do the job.

Robert Walgate 